\title{
Skene's gland cyst as an interlabial mass in a newborn girl
}

\author{
Eliana Costantino, George S Ganesan
}

Children's Urology Associates, Las Vegas, Nevada, USA

\section{Correspondence to}

Eliana Costantino,

elianacb@gmail.com

Accepted 30 March 2016

\section{DESCRIPTION}

The Skene's glands, the largest of the paraurethral glands, have 6-30 ducts merging in the distal urethra. ${ }^{1}$ They secrete mucoid material with sexual stimulation and are considered homologues of the male prostate. Skene's duct cysts are a rare cause of interlabial mass, especially in newborns. ${ }^{2}$ There is a variable incidence of 1:2074-7242, but it may be higher than described in the literature. Maternal oestrogen exposure, obstruction or stenosis of the duct and dislocation of the urothelium have been suggested as causes. The true aetiology remains unknown. ${ }^{1}$

We present a newborn girl found to have a painless bulging interlabial mass (figure 1); the remainder of the examination was normal. Prenatal history was unremarkable. Pelvic ultrasound showed an indeterminate solid isoechoic mass in the region of the urethra, without internal vascularity; no cystic components were identified. Abdominopelvic CT with contrast showed a $7 \times 6 \times 11 \mathrm{~mm}$ cystic lesion in the region of the vagina; no contrast enhancement was seen. Pelvic MRI with and without contrast showed an $11 \times 6 \mathrm{~mm}$ cystic midline perineal mass in a paraurethral location, without enhancement; there were neither vaginal nor uterine anomalies and no obstruction. Urethral catheterisation was performed under anaesthesia, with some difficulty in identifying the urethral opening, which was located on the right lateral wall of the cystic structure (figure 2). Vaginal patency was verified. Voiding cystourethro-

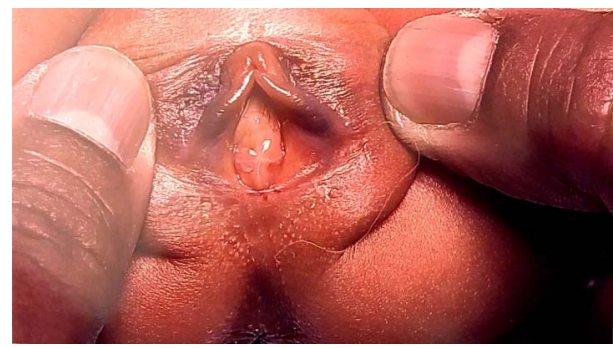

Figure 1 Interlabial mass in a newborn girl.

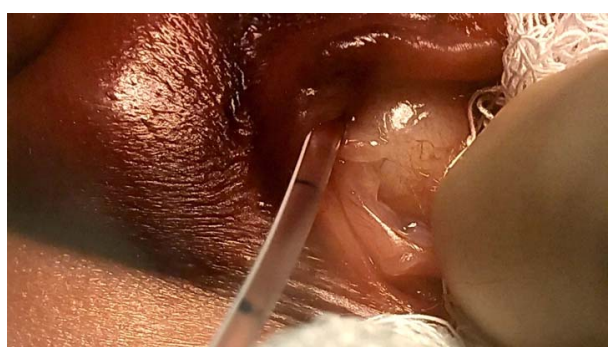

Figure 2 Displacement of the urethral meatus by the paraurethral cyst.

gram was normal. Spontaneous resolution had occurred by follow-up.

Differential diagnoses include imperforate hymen, urethral prolapse, urethral diverticulum, rhabdomyosarcoma of the vagina and prolapsed ectopic ureterocoele. ${ }^{12}$

Treatment options vary on observation, needle aspiration and drainage, excision, unroofing and marsupialisation, usually without recurrence. ${ }^{12}$

\section{Learning points}

- Displacement of the urethral meatus by the mass is a distinctive feature of paraurethral cysts.

- Urinary obstruction should be rule out to provide prompt appropriate management.

- The incidence of Skene's gland cysts may be higher than reported in the literature.

Competing interests None declared.

Patient consent Obtained.

Provenance and peer review Not commissioned; externally peer reviewed.

\section{REFERENCES}

1 Dhapodkar S, Homayoon K. Paraurethral cysts in a female newborn. Open J Urol 2011;1:48-9.

2 Moralioğlu S, Bosnalı O, Celayir AC, et al. Paraurethral Skene's duct cyst in a newborn. Urol Ann 2013;5:204-5. 


\section{Images in...}

Copyright 2016 BMJ Publishing Group. All rights reserved. For permission to reuse any of this content visit http://group.bmj.com/group/rights-licensing/permissions.

BMJ Case Report Fellows may re-use this article for personal use and teaching without any further permission.

Become a Fellow of BMJ Case Reports today and you can:

- Submit as many cases as you like

- Enjoy fast sympathetic peer review and rapid publication of accepted articles

- Access all the published articles

- Re-use any of the published material for personal use and teaching without further permission

For information on Institutional Fellowships contact consortiasales@bmjgroup.com

Visit casereports.bmj.com for more articles like this and to become a Fellow 